\title{
IASI measurements of reactive trace species in biomass burning plumes
}

\author{
P.-F. Coheur ${ }^{1, * *}$, L. Clarisse ${ }^{1, * *}$, S. Turquety ${ }^{2, *}$, D. Hurtmans ${ }^{1}$, and C. Clerbaux ${ }^{2,1}$ \\ ${ }^{1}$ Spectroscopie de l'Atmosphère, Service de Chimie Quantique et de Photophysique, Université Libre de Bruxelles (U.L.B.), \\ Brussels, Belgium \\ ${ }^{2}$ UPMC Univ. Paris 06, Université Versailles St-Quentin, CNRS/INSU, LATMOS-IPSL, Paris, France \\ * now at: UPMC Université Paris 06, Laboratoire de Météorologie Dynamique/IPSL, Ecole Polytechnique, Palaiseau, France \\ ** Research Associate and Scientific Research Worker with the FRS-F.N.R.S, Belgium
}

Received: 18 February 2009 - Published in Atmos. Chem. Phys. Discuss.: 1 April 2009

Revised: 5 August 2009 - Accepted: 5 August 2009 - Published: 10 August 2009

\begin{abstract}
This work presents observations of a series of short-lived species in biomass burning plumes from the Infrared Atmospheric Sounding Interferometer (IASI), launched onboard the MetOp-A platform in October 2006. The strong fires that have occurred in the Mediterranean Basin - and particularly Greece - in August 2007, and those in Southern Siberia and Eastern Mongolia in the early spring of 2008 are selected to support the analyses. We show that the IASI infrared spectra in these fire plumes contain distinctive signatures of ammonia $\left(\mathrm{NH}_{3}\right)$, ethene $\left(\mathrm{C}_{2} \mathrm{H}_{4}\right)$, methanol $\left(\mathrm{CH}_{3} \mathrm{OH}\right)$ and formic acid $(\mathrm{HCOOH})$ in the atmospheric window between 800 and $1200 \mathrm{~cm}^{-1}$, with some noticeable differences between the plumes. Peroxyacetyl nitrate $\left(\mathrm{CH}_{3} \mathrm{COOONO}_{2}\right.$, abbreviated as PAN) was also observed with good confidence in some plumes and a tentative assignment of a broadband absorption spectral feature to acetic acid $\left(\mathrm{CH}_{3} \mathrm{COOH}\right)$ is made. For several of these species these are the first reported measurements made from space in nadir geometry. The IASI measurements are analyzed for plume height and concentration distributions of $\mathrm{NH}_{3}, \mathrm{C}_{2} \mathrm{H}_{4}$ and $\mathrm{CH}_{3} \mathrm{OH}$. The Greek fires are studied in greater detail for the days associated with the largest emissions. In addition to providing information on the spatial extent of the plume, the IASI retrievals allow an estimate of the total mass emissions for $\mathrm{NH}_{3}, \mathrm{C}_{2} \mathrm{H}_{4}$ and $\mathrm{CH}_{3} \mathrm{OH}$. Enhancement ratios are calculated for the latter relative to carbon monoxide (CO), giving insight in the chemical processes occurring during the transport, the first day after the emission.
\end{abstract}

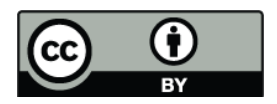

Correspondence to: P.-F. Coheur (pfcoheur@ulb.ac.be)

\section{Introduction}

Most of the processes driving atmospheric chemistry occur on time scales of seconds to days. The species involved, highly reactive, are present in the atmosphere in small concentrations and are mostly hard to track in space and time. When released at the surface as primary pollutants, they react rapidly close to the source region, except for a small fraction that survives boundary layer chemistry, escapes to the free troposphere and is transported to regions downwind. The distance travelled strongly depends upon the species chemical lifetime, the latter being in turn strongly influenced by the local chemical and thermodynamic conditions.

Of particular interest is the monitoring close to the surface of constituents which impact, directly or not, human health and ecosystems. These species are controlled in industrialized countries by air quality standards, which are defined in terms of the ambient abundance of ozone $\left(\mathrm{O}_{3}\right)$, nitrogen oxides $\left(\mathrm{NO}_{\mathrm{x}}\right)$, sulfur dioxide $\left(\mathrm{SO}_{2}\right)$, carbon monoxide $(\mathrm{CO})$ and particulate matter $\left(\mathrm{PM}_{2.5}\right.$ and $\left.\mathrm{PM}_{10}\right)$. Ozone itself is a secondary pollutant which is formed by complex reaction mechanisms involving $\mathrm{NO}_{\mathrm{x}}$, methane $\left(\mathrm{CH}_{4}\right), \mathrm{CO}$ and a large series of volatile organic compounds (VOCs).

Ground-based instruments located nearby source regions, such as urban areas, are obviously best suited for measuring reactive species in the boundary layer, as they offer at the same time a high sensitivity (down to a few parts per trillion $-10^{-12}$ - in fractional concentration), accuracy and repetitiveness. They are therefore important for the local air quality surveillance and forecast systems. However, they are unable to resolve and track pollution plumes in space and time and can only partly contribute, for instance, to the study of transboundary transport of pollution. In recent years,

Published by Copernicus Publications on behalf of the European Geosciences Union. 
nadir-looking satellite instruments have greatly helped drawing the grand picture of tropospheric pollution by measuring a series of primary and secondary reactive gaseous pollutants down to the surface, from the local to the global scale (Martin, 2008 and references therein). Routine observations include $\mathrm{NO}_{2}, \mathrm{SO}_{2}, \mathrm{H}_{2} \mathrm{CO}, \mathrm{C}_{2} \mathrm{H}_{2} \mathrm{O}_{2}$ and halogen compounds from UV-visible sounders (Wagner et al., 2008 and references therein), and principally $\mathrm{O}_{3}, \mathrm{CO}$ and $\mathrm{CH}_{4}$ from infrared sounders (e.g. Clerbaux et al., 2003, 2009). Recently the possibility of probing $\mathrm{NH}_{3}$ and methanol $\left(\mathrm{CH}_{3} \mathrm{OH}\right)$ from TIR radiances was demonstrated (Beer et al., 2008), adding to the potential of TIR sounding missions in contributing to monitor the fast chemistry of the lower troposphere. Considering this, the recently launched Infrared Atmospheric Sounding Interferometer (IASI) onboard MetOp-A, which has unique spatial resolution and sampling, is expected to benefit the surveillance of the atmospheric system, operationally, and from a local to a global scale (Clerbaux et al., 2007).

In this work, we intend to go a step further by showing that TIR sounders can be used to identify and quantify a range of short-lived chemical species that are not observed in background atmospheric situations. For this purpose, we focus our study on IASI measurements above fire plumes from the 2007 wildfires in the Mediterranean basin (Boschetti et al., 2008; Turquety et al., 2009) and the spring 2008 boreal fires in Southern Siberia - Baikal Lake area (Warneke et al., 2009) - and Eastern Mongolia. Fire plumes are chosen because of the expected elevated concentrations of gases and particles released simultaneously in the boundary layer and because of the usual high reactivity of these extreme environments (e.g. Andreae and Merlet, 2001). Large biomass fires are furthermore known to significantly affect air quality conditions prevailing locally, especially when the plume is confined in the boundary layer, but also regionally when the plume is emitted in the free troposphere and transported downwind over long distances (Langmann et al., 2009 and references therein). The local impact is mostly due to the release of particles which remain close to the emission point, whereas the regional impact is mostly related to the emission and transport of ozone precursors, such as $\mathrm{CO}, \mathrm{NO}_{2}$, and VOCs, the chemistry of which can induce large surface ozone concentrations farther away (Langmann et al., 2009; Pfister et al., 2008; Morris et al., 2006).

The next section provides an overview of the measurements and the relevant theoretical elements. These include a brief description of IASI, of the two fire events examined here, and of the inverse method used to retrieve trace gas abundances from the spectra. Section 3 reports on the detailed spectroscopic analysis of different fire plumes, focusing on the assignment of spectral features to species rarely measured before from satellite observations. This section includes a focused discussion of the Greek fires, giving insights on the chemistry processes occurring during the first $24 \mathrm{~h}$ after the plume's emission. We then draw conclusions and open perspectives for further research, notably in regard to the possibility to obtain global distributions for some of the newly species observed.

\section{Measurements}

\subsection{IASI}

A detailed description of IASI is provided by Clerbaux et al. (2009) in this special issue. As compared to other thermal infrared sounders in orbit, the IASI advanced Fourier transform spectrometer, offers a large and continuous spectral coverage of the infrared region $\left(645-2760 \mathrm{~cm}^{-1}\right)$, at a medium spectral resolution $\left(0.5 \mathrm{~cm}^{-1}\right.$ apodized $)$. The IASI spectra are dominated by rotation-vibration transition lines of $\mathrm{H}_{2} \mathrm{O}, \mathrm{CO}_{2}, \mathrm{CH}_{4}, \mathrm{~N}_{2} \mathrm{O}, \mathrm{O}_{3}$ and $\mathrm{CO}$, and also allow providing key information on surface properties using atmospheric windows. Given the high radiometric performances, weak absorption features such as for instance $\mathrm{HNO}_{3}$ (Wespes et al., 2009) and CFCs (Coheur et al., 2003) are seen on each individual observations. The spectral information contained in the measurements are used to tackle the primary objective of IASI, which is to support operational numerical weather predictions by providing accurate and highly resolved vertical profiles of temperature (from the $\mathrm{CO}_{2}$ lines) and humidity (from the $\mathrm{H}_{2} \mathrm{O}$ lines) (Schlüssel et al., 2005). The observations of greenhouse gases and reactive species in the IASI spectra, and in particular $\mathrm{O}_{3}$ and $\mathrm{CO}$ allow climate and atmospheric chemistry issues to be tackled as well, also opening perspectives for operational applications (Clerbaux et al., 2007).

The IASI sounder currently in orbit is the first of a series of three successive instruments that are part of Europe's polar orbiting meteorological satellites (MetOp), dedicated for operations in the 2006-2020 timeframe. Being designed primarily to meet the needs of meteorology, it provides a global coverage of the Earth surface twice daily with a relatively small pixel size on the ground ( $12 \mathrm{~km}$ at nadir). This high spatial and temporal sampling capability along with the spectral and radiometric performances of the FTS, offer a unique support for identifying local and sudden emissions at the surface and for following the fate and transport of the resulting pollution plumes. Typical applications are for instance found in the monitoring of volcanic eruptions (Clarisse et al., 2008) and fires (Turquety et al., 2009), using signatures of $\mathrm{SO}_{2}$ and $\mathrm{CO}$, respectively.

\subsection{Radiance and brightness temperature spectra}

Thermal infrared nadir sounders measure the radiation emitted by the Earth, modified by atmospheric extinctions (absorption and scattering) and emissions along the path. The spectra measured at the top of the atmosphere are expressed as radiance $\left(\mathrm{W} / \mathrm{cm}^{2} \mathrm{srcm}^{-1}\right)$, which represent the outgoing flux collected within a solid angle at a given wavenumber, 
per unit of surface. The radiance spectra can be conveniently transformed to brightness temperature spectra, by inverting the source function, usually represented by a grey body (Planck blackbody function multiplied by the surface emissivity). In a so-called window channel without atmospheric absorption, the brightness temperature associated to a scene with unitary emissivity would be equal to the Earth's surface temperature. Extinction and emission processes occurring in the atmosphere at a given wavenumber $\tilde{v}$ cause the brightness temperature to be respectively lower and higher than the surface temperature in a nearby window channel. Accordingly, the difference in brightness temperature between a perturbed and a reference window channel, hereafter BTD, can be used as a probe for the presence of absorption or emission features in the spectra. The use of BTDs is common for multispectral sounding and represents a fast and robust method for the identification and tracking of sudden events such as volcanic plumes (Clarisse et al., 2008).

\subsection{Concentration measurements}

Retrieving trace gas abundances from IASI spectra is done by adjusting onto the measurement a simulated radiance spectrum, computed from the radiative transfer equations using our best knowledge of the atmospheric state at the time and place of the observation. In the forward model, a particular care has to be given to the local meteorological conditions, characterized by pressure, temperature and humidity profiles, as well as to the surface type and emissivity. For this work we use pressure, temperature and humidity vertical profile (Level 2) products disseminated operationally by EUMETSAT (Schlüssel et al., 2005). The preliminary validation of these level 2 meteorological products reports an accuracy close to the mission objectives: for temperature the error is $0.6 \mathrm{~K}$ in the free troposphere, increasing to $1.5-2 \mathrm{~K}$ at the surface and in the upper troposphere with a bias of $\pm 0.5 \mathrm{~K}$, while for the relative humidity the error is $10 \%$ with a bias within $\pm 10 \%$ (Pougatchev et al., 2009). These parameters are kept fixed in the inversion process, except for the surface temperature and the humidity profiles which are adjusted to provide the best possible fits in the spectral regions of interest. For the Greek fires in 2007, the Level 2 data were not available and the pressure and temperature data for the corresponding scenes were therefore taken from the European Center for Medium Weather Forecast (ECMWF), interpolated to match the time and place of the measurements. For the emissivity, an average value from the 12 channels from MODIS/Terra climatology are used (Wan, 2008). The spectroscopic parameters, including line parameters and absorption cross sections for CFCs, are from the HITRAN database (Rothman et al., 2005). For $\mathrm{CH}_{3} \mathrm{COOH}$, missing in HITRAN, the cross sections from the PNNL-Vapor phase infrared spectral library (Sharpe et al., 2004) are used. Also the water vapour and carbon dioxide are taken into account using the MT-CKD formulations (Clough et al., 2005).
As nadir measurements integrate all photophysical processes occurring over the vertical altitude range of the atmosphere, one can typically hope to extract total column amounts. For a given species, this is usually done by scaling a reference profile iteratively such as to reproduce the amplitude of the observed spectral features as close as possible. For some gases, however, weakly resolved vertical profiles can be derived as well, considering the pressure and temperature dependences of their spectra. The problem becomes unfortunately ill-conditioned and can only be solved by using constrained retrieval approaches. The Optimal Estimation (Rodgers, 2000) is the most widely used method for remote sensing purposes. It is implemented in the Atmosphit software, which includes a full line-by-line radiative transfer model, as well as in the FORLI (Fast Operational/Optimal Retrieval on Layers for IASI) dedicated software for nearreal time and large scale processing of IASI since 2007. In this work, we have used the Atmosphit software for all species except $\mathrm{CO}$, which is routinely processed by FORLI$\mathrm{CO}$ in the group (George et al., 2009). The theoretical approaches of both algorithms are extensively described elsewhere (Clarisse et al., 2008; Coheur et al., 2005; Turquety et al., 2009; Wespes et al., 2009).

The trace gases profiles used for the forward model and the retrievals with Atmosphit in the atmospheric window are from the US standard atmospheres (US Government Printing Office, 1976), scaled in the case of $\mathrm{CO}_{2}$ to a vmr of 385 ppmv. Exceptions are $\mathrm{O}_{3}, \mathrm{CH}_{4}$ and $\mathrm{HNO}_{3}$, for which the prior are global averaged yearly profiles from climatology, used along with the associated covariance matrices (Turquety et al., 2004; Wespes et al., 2009) and for $\mathrm{CH}_{3} \mathrm{OH}$ and $\mathrm{C}_{2} \mathrm{H}_{4}$ for which we use global averaged profiles from the LMDz model (Hauglustaine et al., 2004). For these two species and for $\mathrm{NH}_{3}$, which are central to this paper, we allow a large variability in the retrieval of vertical profiles $(6$ layers of $3 \mathrm{~km}$ thickness are retrieved although the objective is not to deduce vertically resolved information due to the weak signals). This is done by using an ad-hoc covariance matrix with very large variability (diagonal elements) and by considering for the off-diagonal elements a simple exponential decay with $7 \mathrm{~km}$ correlation length. These assumptions on the variance-covariance matrix, which are required to capture the large values of concentrations in the plume are unrealistic in the geophysical sense, and do accordingly not allow for a comprehensive posterior characterization of the retrieved products in terms of vertical sensitivity and errors. Hence averaging kernels will not be shown in the following and the reported retrieval errors, which do not properly represent the vertical smoothing and do not account for the possible impact of e.g. aerosols, should be taken with caution. As a result of this also, some of the retrieved quantities which will be discussed next, in particular the total emitted mass, should mainly be considered as indicative. 


\subsection{Selected fire events}

This paper concentrates on two large fire events that occurred in the Northern Hemisphere since the IASI launch in October 2006: the August 2007 wildfires in the Mediterranean basin and the April-May 2008 boreal fires in Southern Siberia and Eastern Mongolia, in the vicinity of the Baikal Lake.

The wildfires in the Mediterranean basin are relatively well documented (Boschetti et al., 2008; EFFIS, 2008) and also discussed more thoroughly by Turquety et al. (2009). They lasted for several days and burned close to 900 thousands hectares, with about one third in Greece (EFFIS, 2008), which experienced that year the worst fire situation on record. In Greece the fires have been extremely severe due to combination of persistent high temperatures (3 consecutive heat waves), drought and strong winds. The fires were particularly intense in the last week of August 2007 in the Peloponnese (22 to 30 August), with five major fires burning 170000 hectares (ha) and releasing a large quantity of gases and particles in the atmosphere. Unusually elevated $\mathrm{CO}$, well above several parts per million by volume mixing ratios in the boundary layer, have for instance been reported close to the fire source (Turquety et al., 2009). Rapid transport at relatively low altitude (estimated around 3-5 km) caused increased $\mathrm{CO}$ level above most part of the Mediterranean basin during these days.

The wildfires in Kazakhstan and Southern Siberia in April 2008 were also exceptional, starting earlier than usual due to relative high temperatures and low levels of precipitation. Before the end of April, more than 900 large-scale fires were reported, with 36000 ha of forest being devastated, likely resulting from human negligence. This event was amongst the worst that Russia experienced in the last 30 years. Large fires were in particular reported in the area between the Baikal Lake and the Amur River between 17 and 24 April. Unlike the ones in Kazakhstan Southern-Siberia region, which were attributed to agricultural practices, those in the Baikal area are likely due to forest fires (Warneke et al., 2009). Another relatively important burning episode occurred later in mid May in a nearby region in Eastern Mongolia, lasting a few days only. Besides their importance for local air quality, pollutants emitted by these high latitude fires in the Northern Hemisphere are also important due to rapid transport to the remote Arctic (Stohl, 2006), playing a role in the development of the so-called Arctic haze and the lowering of the surface albedo (Law and Stohl, 2007; Generoso et al., 2007). This has been the case for the Baikal fires of April, which have been monitored by the NOAA WP-3D aircraft during the airborne field experiment ARCPAC (Aerosol, Radiation and Cloud Processes affecting Arctic Climate), over Northern Alaska and the Arctic sea ice (Warneke et al., 2009). The transported plumes were sampled by a suite of airborne instruments at relatively low altitude, from the surface to $6.5 \mathrm{~km}$ in the free troposphere, which corresponds to the highest flight altitude for the WP-3D (Warneke et al., 2009).

\section{Results}

\subsection{Spectroscopic analyses}

Figure 1 presents IASI observations of a fire plume originating from the Baikal region $\left(49.50^{\circ} \mathrm{N}, 110.32^{\circ} \mathrm{E}\right)$, on 18 April 2008, around 20:50 local time. Two brightness temperature spectra are highlighted (red and blue curves), covering the atmospheric window from 800 to $1200 \mathrm{~cm}^{-1}$ and the $\mathrm{CO}$ 1-0 rotation-vibration band from 2050 to $2220 \mathrm{~cm}^{-1}$. Residual spectra are also shown. These were calculated by subtracting from the two target spectra within the plume a spectrum recorded nearby in background conditions (grey lines in Fig. 1), which was chosen to have similar surface temperatures and ozone and humidity concentrations. This allows the removal of all major background lines in these spectral regions. The residual spectrum in red shows strong features emerging from the background, all with negative BTD values, which indicate the occurrence of additional absorptions in the fire plumes. On the shortwave end these spectral features are rotational lines of the $\mathrm{CO}$ fundamental band. Their large negative BTD values of $-10 \mathrm{~K}$ and below indicate strong concentration enhancements of that species in the fire plume. In the atmospheric window, the residual features are principally due, as will be shown next, to ammonia and several volatile organic compounds, not observed in the background spectra. Interestingly, the spectrum plotted in blue in Fig. 1 shows the same features but with positive BTD values, suggesting the presence of an emitting layer of gases and/or particles in the path, at a temperature higher than that of the source. This would be consistent with the IASI temperature profiles provided by EUMETCast, which shows an inversion layer at about $2.2 \mathrm{~km}$ (Fig. 1, right panel), and may give indication, as extensively discussed in Clarisse et al. (2009b), of the altitude of the plume at this location, i.e. within or just above the boundary layer. More generally, the temperature variations in the lowest layer of the troposphere and in particular the difference in temperature between the surface and the air just above it (the thermal contrast) is well known to strongly regulate the sensitivity of infrared sounders in the low troposphere. The spectrum with strong absorption lines in Fig. 1 (shown in red with negative BTD values) has for instance a surface temperature of $296 \mathrm{~K}$ and a much lower air temperature of $272 \mathrm{~K}$ (right panel of Fig. 1); the resulting high positive thermal contrast greatly enhances the sensitivity of the sounder to the surface. If the emitted fire plume was in the boundary layer, this higher sensitivity would be a good demonstration of IASI probing the lowermost atmospheric layers. The observation of South Siberian fire plumes made later above Alaska and the Arctic Sea below $6.5 \mathrm{~km}$ (Warneke et al., 2009) tend to confirm that the plume was emitted and transported at relatively low altitude. It is worth pointing out that the situation described here, where we would have observed for an evening scene both emission and absorption spectra with contribution from the boundary 

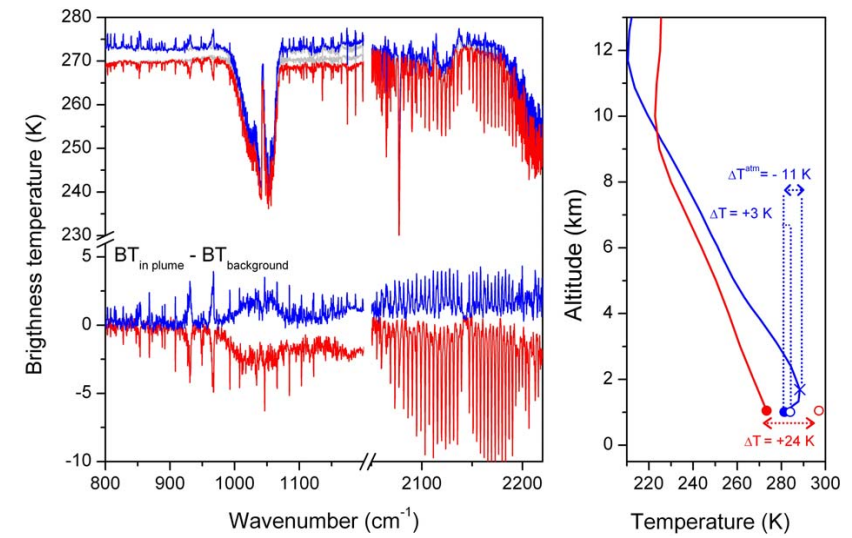

Fig. 1. Left: example of IASI observations of ammonia in a fire plume in the vicinity of the Baikal Lake (see Fig. 2), on 18 April 2008, around 20:50 local time. Two example spectra within the plume are shown, with focus on the spectral regions from 800 to $1200 \mathrm{~cm}^{-1}$ and 2050 to $2220 \mathrm{~cm}^{-1}$. The residual spectra in the Figure are obtained by subtracting nearby background spectra, shown in grey line, with similar temperature, humidity and ozone (note the weak presence of the latter in the residual between 1000 and $1100 \mathrm{~cm}^{-1}$ ). The residuals show both positive (blue) and negative values (red), corresponding to unusual emission and absorption features from the fire plumes. Above $2100 \mathrm{~cm}^{-1}$, these clearly show the enhancements of $\mathrm{CO}$ concentrations as compared to background situations. In the atmospheric window, these features are attributable to $\mathrm{NH}_{3}$ and a series of VOCs. Right: temperature profile corresponding to the two fire spectra, with the thermal contrast $(\Delta T)$ values indicated. The temperatures are those disseminated operationally by EUMETCast.

layer is uncommon, as IASI shows in general greater sensitivity to the surface during its morning orbit, when the thermal contrast can reach high positive value (Clarisse et al., 2009b). On 18 April the observations of remarkable emission/absorption features in the IASI spectra extend over a wide area, located between the Baikal Lake and River Amur, as displayed in Fig. 2 using BTDs between a channel sensitive to $\mathrm{NH}_{3}$ at $867.75 \mathrm{~cm}^{-1}$ and two window channels located on each side of it (at $861.25 \mathrm{~cm}^{-1}$ and $873.50 \mathrm{~cm}^{-1}$ ).

Figure 3 shows spectral fits in the region $800-1200 \mathrm{~cm}^{-1}$, for the spectrum plotted in Fig. 1. The fitted spectrum was obtained by adjusting the columns or profiles for all species absorbing in that spectral region $\left(\mathrm{O}_{3}, \mathrm{H}_{2} \mathrm{O}, \mathrm{CO}_{2}\right.$, $\mathrm{HNO}_{3}, \mathrm{CFC} 11$ and $\mathrm{CFC12}$ ) along with surface temperature, but excluding ammonia $\left(\mathrm{NH}_{3}\right)$, ethene $\left(\mathrm{C}_{2} \mathrm{H}_{4}\right)$ and methanol $\left(\mathrm{CH}_{3} \mathrm{OH}\right)$. The assignment of the enhanced features in the plume spectra seen in Fig. 1 to these three compounds becomes unambiguous when comparing the residual spectrum (observed-fitted, middle panels of Fig. 3), to the calculated transmittance of the missing species (bottom panels of Fig. 3). The $\mathrm{NH}_{3}$ spectrum is particularly visible, extending over almost $400 \mathrm{~cm}^{-1}$, with two noticeable $Q$-branches and several strong lines, all belonging to the $\nu_{3}$

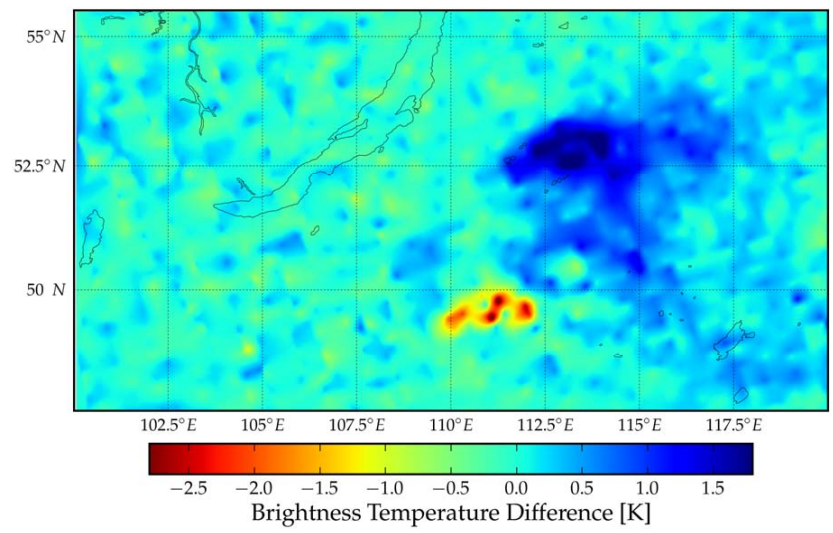

Fig. 2. IASI observations of ammonia in a fire plume in the vicinity of the Baikal Lake, on 18 April 2008 (20:50 local time). The figure shows the spatial distribution of the plume, using the $\mathrm{NH}_{3}$ signal, expressed in brightness temperature difference between a channel sensitive to $\mathrm{NH}_{3}$ at $867.75 \mathrm{~cm}^{-1}$ and two window channels at $861.25 \mathrm{~cm}^{-1}$ and $873.50 \mathrm{~cm}^{-1}$. Note the positive and negative values, representing features in emission and absorption, respectively. The spatial extension of the plume is revealed by the high values, above $+0.8 \mathrm{~K}$ and below $-0.8 \mathrm{~K}$; the values lying in between these thresholds are mostly representative of the noise level. Two typical spectra from these plumes are displayed in Fig. 1.

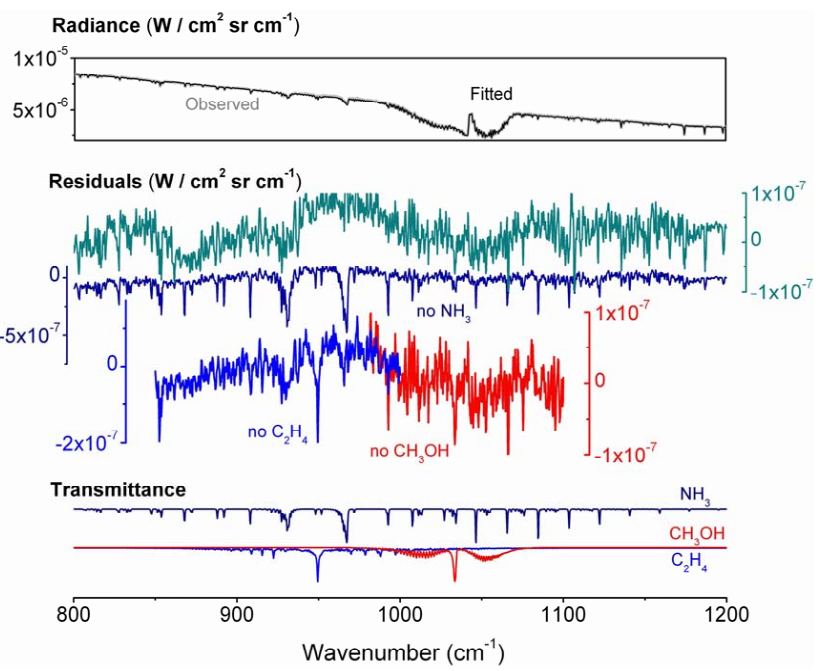

Fig. 3. Top: observed and fitted IASI radiance spectra from the fires in the Baikal area (observation made on 18 April at $49.50^{\circ} \mathrm{N}$, $110.32^{\circ} \mathrm{E}$; see Fig. 1 red curve), with all species included in the retrieval except $\mathrm{NH}_{3}, \mathrm{C}_{2} \mathrm{H}_{4}$ and $\mathrm{CH}_{3} \mathrm{OH}$. Middle: spectral residuals (observed-fitted spectrum) with all species in the retrieval (dark cyan), without $\mathrm{NH}_{3}$ (dark blue), without $\mathrm{C}_{2} \mathrm{H}_{4}$ (blue) and without $\mathrm{CH}_{3} \mathrm{OH}$ (red). Bottom: simulated transmittance for $\mathrm{NH}_{3}, \mathrm{C}_{2} \mathrm{H}_{4}$ and $\mathrm{CH}_{3} \mathrm{OH}$ alone, with arbitrary concentrations. See text for details. 
band. For $\mathrm{C}_{2} \mathrm{H}_{4}$ and $\mathrm{CH}_{3} \mathrm{OH}$, it is essentially the $Q$-branch, of respectively the $v_{7}$ and $v_{8}$ bands, that show up. One should point out that the $\mathrm{CH}_{3} \mathrm{OH}$ spectrum is strongly overlapped by that of ozone.

Figure 4 provides a similar comparison in the region from 1070 to $1250 \mathrm{~cm}^{-1}$, which is a relatively transparent window, containing several water lines of medium intensity and additional weaker contribution of $\mathrm{O}_{3}, \mathrm{~N}_{2} \mathrm{O}$ and CFC12. In the plume, however, this portion of the spectrum is significantly affected by broadband extinctions. In Fig. 4 this is shown for two spectra, one which is the same as that of Figs. 1 and 3, the other corresponding to a fire plume from 17 May in Eastern Mongolia $\left(46.09^{\circ} \mathrm{N}, 118.99^{\circ} \mathrm{E}\right.$, 11:07 local time), also revealing signatures of $\mathrm{NH}_{3}, \mathrm{CH}_{3} \mathrm{OH}$ and $\mathrm{C}_{2} \mathrm{H}_{4}$. Among these broadband features, one, which is mostly visible in the 17 May spectrum, is unambiguously attributable to formic acid $(\mathrm{HCOOH})$ in its $v_{6}$ band, with a marked $Q$-branch at $1105 \mathrm{~cm}^{-1}$. Further extinction, on the shortwave end of this spectral portion, is tentatively assigned here to acetic acid $\left(\mathrm{CH}_{3} \mathrm{COOH}\right)$, possibly amplified by peroxyacetyl nitrate (PAN), both with absorptions in the $\mathrm{CO}$ stretching mode. The assignment to PAN is in fact more certain for the 17 May plume, considering that an additional spectral band of that species $\left(\mathrm{NO}_{2}\right.$ bending mode) is well visible between 760 and $830 \mathrm{~cm}^{-1}$ (middle vertical panel in Fig. 4). For this spectrally rich plume the following total columns are retrieved: $\left[\mathrm{NH}_{3}\right]=5.7 \pm 0.1$, $\left[\mathrm{C}_{2} \mathrm{H}_{4}\right]=2.2 \pm 0.3,\left[\mathrm{CH}_{3} \mathrm{OH}\right]=5.1 \pm 0.7,[\mathrm{HCOOH}]=5.2 \pm 0.2$, $\left[\mathrm{CH}_{3} \mathrm{COOH}\right]=0.6 \pm 0.2,[\mathrm{PAN}]=2.0 \pm 0.1$, all expressed in $10^{16}$ molecules $\mathrm{cm}^{-2}$. We stress that the errors given here on the columns are the statistical $(1 \sigma)$ retrieval errors, which may not be representative considering the assumptions made on the variance-covariance matrices (see Sect. 2.3.) and the fact that possible interferences by e.g. aerosols, have not been taken into account. Furthermore, although vertical profiles are retrieved, the number of independent pieces of information (the so-called degrees of freedom for signal - DOFS in the Optimal Estimation Method) is for most species not larger than one, suggesting that only a column can be retrieved. Only in the case of $\mathrm{NH}_{3}$, for which the signal is strongest, the DOFS gets occasionally to 1.5 but this value remains tributary, however, of the large variability allowed in the retrieval. In the following we therefore only use column abundances. We note in addition that other classic fire tracers, including $\mathrm{C}_{2} \mathrm{H}_{2}, \mathrm{C}_{2} \mathrm{H}_{6}, \mathrm{H}_{2} \mathrm{CO}, \mathrm{HCN}$ and $\mathrm{CH}_{3} \mathrm{CN}$ have not been identified in these IASI spectra. For $\mathrm{C}_{2} \mathrm{H}_{2}$ and $\mathrm{HCN}$ this could be due in part because their main absorption bands lie in a $\mathrm{CO}_{2}$-saturated region of the spectrum below $750 \mathrm{~cm}^{-1}$, while for $\mathrm{H}_{2} \mathrm{CO}$ this is explainable to the weak lines in the near infrared above $2500 \mathrm{~cm}^{-1}$, where the noise performances of IASI are significantly reduced. For $\mathrm{C}_{2} \mathrm{H}_{6}$ and $\mathrm{CH}_{3} \mathrm{CN}$ the reason is unclear and in all cases not attributable to instrumental limitations.

Comparing the different fire plumes, it is worth stressing that unlike the spectra of 18 April in the Baikal region, the temperature profile for the 17 May case in Eastern Mongolia is not associated with a favourable thermal contrast situation (a $\Delta T$ of $-6 \mathrm{~K}$ prevails for the example spectrum of Fig. 4). The observation of $\mathrm{NH}_{3}$ and VOCs in these fires may therefore point to a higher altitude of the plume, well above the boundary layer, where the IASI measurements are by nature more sensitive. The injection of fire plumes directly into the free troposphere can take place through different convection mechanisms (e.g. Freitas et al., 2007), but are relatively infrequent (Freitas et al., 2007; Labonne et al., 2007). These injections are for instance estimated to be on the order of $10 \%$ in boreal regions (Hyer et al., 2007; Kahn et al., 2008), where they can be exceptionally exacerbated during violent pyro-convective events (Damoah et al., 2006; Fromm and Servranckx, 2003). The lack of vertical sensitivity of IASI to trace gas profiles does not allow for a precise estimate of the injection height and cannot confirm this: although useful information can be extracted from the $\mathrm{CO}$ vertical profiles in favourable situations (Turquety et al., 2009), this is unfortunately not the case for the observation discussed here, for which the retrieved $\mathrm{CO}$ profile does not reveal any fine structure on the vertical.

The species firmly $\left(\mathrm{NH}_{3}, \mathrm{C}_{2} \mathrm{H}_{4}, \mathrm{CH}_{3} \mathrm{OH}, \mathrm{HCOOH}\right)$ or more tentatively (PAN, $\mathrm{CH}_{3} \mathrm{COOH}$ ) detected by IASI in the Siberia/Eastern Mongolia fire plumes are well known relatively short-lived biomass burning products (Andreae and Merlet, 2001), with lifetimes in the boundary layer ranging from a few hours $\left(\mathrm{NH}_{3}\right)$ to several days $\left(\mathrm{CH}_{3} \mathrm{OH}\right)$, increasing for all species to several days/weeks at higher altitudes. These species have for instance been measured before by a variety of instruments, including for some ground- (Rinsland et al., 2005) or airborne-based infrared Fourier transform spectrometers (e.g. Yokelson et al., 1999, 2003; Worden et al., 1997). Their observations from space were, however, very sparse until recently. $\mathrm{HCOOH}$ (Rinsland et al., 2006), $\mathrm{CH}_{3} \mathrm{OH}$ (Dufour et al., 2006, 2007) and $\mathrm{C}_{2} \mathrm{H}_{4}$ (Herbin et al., 2009) have now been extensively studied from the ACEFTS solar occultation spectra in the upper troposphere (see also Rinsland et al., 2007). $\mathrm{NH}_{3}$ and PAN have in addition been observed in a particular young biomass burning plume with the same instrument (Coheur et al., 2007) and by the MIPAS/Envisat limb emission spectrometer on larger scale (Burgess et al., 2006; Glatthor et al., 2007). More recently $\mathrm{CH}_{3} \mathrm{OH}$ and $\mathrm{NH}_{3}$ have been observed in a nadir mode by the Tropospheric Emission Spectrometer (TES) on a case basis (Beer et al., 2008). The results presented here thus provide the first observations of $\mathrm{C}_{2} \mathrm{H}_{4}, \mathrm{HCOOH}, \mathrm{PAN}$ and $\mathrm{CH}_{3} \mathrm{COOH}$ for nadir sounding instruments. Furthermore, this is the first time that the simultaneous measurement of all above-mentioned species in fire plumes is made with such high spatial resolution, coverage and temporal sampling. As shown in the next section, this opens the way to support studies in relation to the chemistry processes in the fires plumes, which are currently mostly undertaken by confronting local ground based or airborne observations to sophisticated 


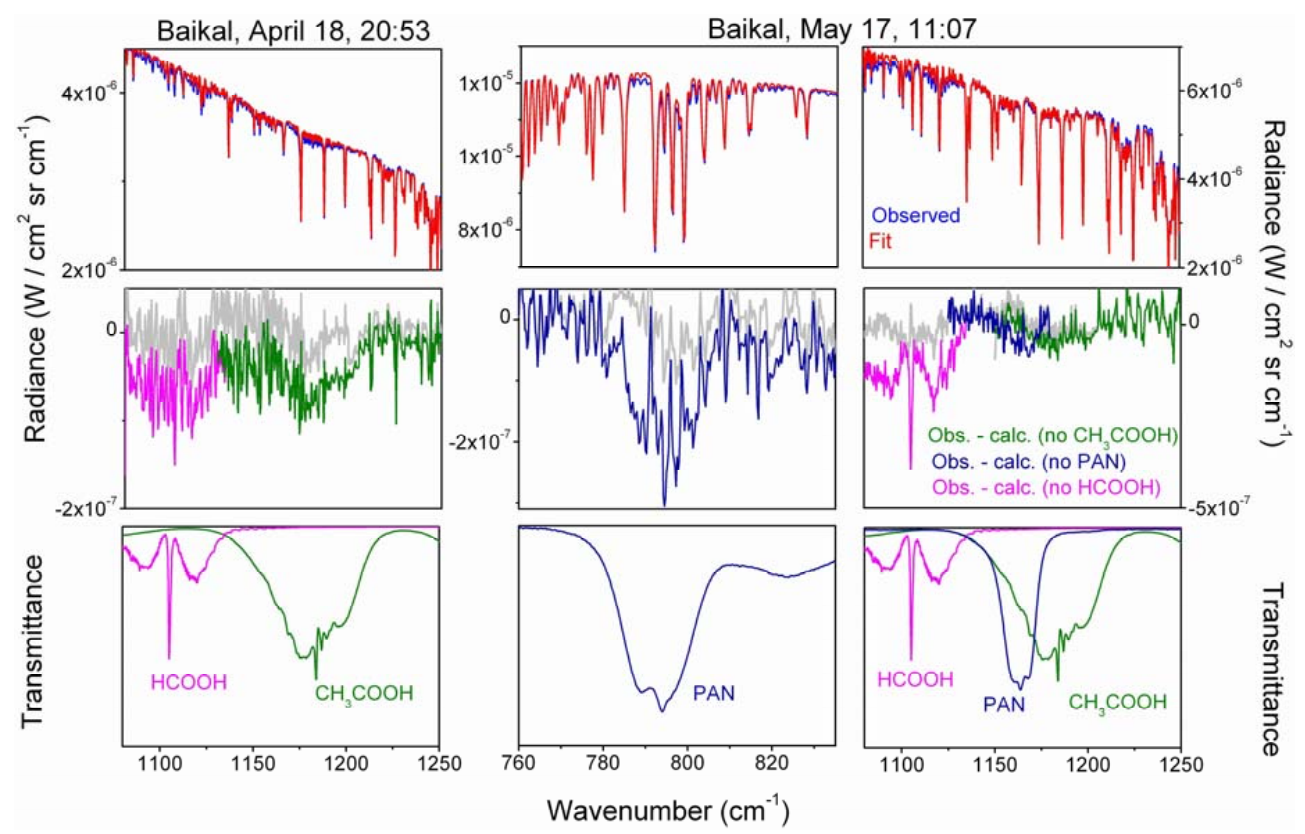

Fig. 4. Same as Fig. 3 (left panel) also shown for a spectrum measured on 17 May in Eastern Siberia $\left(46.09^{\circ} \mathrm{N}, 118.99^{\circ} \mathrm{E}, 11: 07\right.$ local time, middle and right vertical panels). The focus is given here to the region $1075-1250 \mathrm{~cm}^{-1}$, with contributions from $\mathrm{HCOOH} v_{6}$ band, $\mathrm{CH}_{3} \mathrm{COOH}$ and PAN (CO stretching modes), and to the region from 760 to $835 \mathrm{~cm}^{-1}$ with contribution from PAN ( $\mathrm{NO}_{2}$ bending mode). In the middle panels, the light gray lines are the spectral residuals with all species accounted for in the retrieval, indicative of the best achievable RMS.

chemistry and transport models (Jost et al., 2003; Mason et al., 2001, 2006; Trentmann et al., 2003, 2005).

\subsection{Emission and chemistry in the fire plumes}

The large fires that occurred in Greece in the summer of 2007, which lasted for several days, are a good basis for performing a prospective study on the capabilities of IASI to track fire plumes from their emission source to regions downwind, as thoroughly discussed in a companion paper by Turquety et al. (2009), and also for capturing the chemical processes occurring in the first hours using the available information on the shorter lived species. Figure 5 (left panel) is similar to Fig. 3 in all respects, showing one typical IASI spectrum from the Greek fires on 25 August in the evening, when the emissions were largest, and the corresponding spectral fits in the atmospheric window. The $\mathrm{NH}_{3}, \mathrm{C}_{2} \mathrm{H}_{4}$ and $\mathrm{CH}_{3} \mathrm{OH}$ bands are clearly identified in the plume, transported here from Peloponnese to the Mediterranean Sea by North Eastern winds (Fig. 6). In contrast to the fires in South Siberia/Eastern Mongolia described previously, the spectral signatures of $\mathrm{HCOOH}, \mathrm{CH}_{3} \mathrm{COOH}$ and PAN are not detectable here, which could be explained by the larger amounts of VOCs emitted from boreal fires (Mason et al., 2006). For the particular spectrum shown in Fig. 5 we calculate total columns for $\mathrm{NH}_{3}, \mathrm{CH}_{3} \mathrm{OH}$ and $\mathrm{C}_{2} \mathrm{H}_{4}$ of, respectively $5.09 \pm 0.310^{17}, 6.78 \pm 2.010^{16}$ and $1.22 \pm 1.610^{17}$ molecules $\mathrm{cm}^{-2}$, with volume mixing ratios near the surface (essentially scaled versions of the prior profile due to the absence of vertical information) reaching 200 ppbv for $\mathrm{NH}_{3}$, somewhat less for the two organic compounds. Elevated concentrations are also retrieved from IASI for $\mathrm{CO}$, reaching $2.7410^{19}$ molecules $\mathrm{cm}^{-2}$ with exceptional volume mixing ratios well above several ppmv in the boundary layer (Turquety et al., 2009). The range of column abundances retrieved from IASI can not directly be compared to other measurements inside biomass burning plumes, which sample the atmosphere only at low altitude.

The large plume of 25 August shown in Fig. 6 was found to be relatively localized at the time of the IASI first overpass in the morning (08:20 local time). It then extended over a much wider area in the evening (19:40 local time), reaching the African coasts on the 26th in the morning (between 08:00 and 09:40). This transport pattern is well seen in Fig. 7 on the basis of the $\mathrm{NH}_{3}$ signal. It is fully consistent with the transport of $\mathrm{CO}$ and aerosols (Turquety et al., 2009). We find the highest concentrations in the different species in the plume from the 25th in the afternoon, showing that intense burning persisted during the entire daytime, lessening afterwards. The concentrations retrieved in the plume on the 26th in the morning have significantly decreased as a result of fast chemical processes but obviously also because of dilution in the ambient air. Assuming here that most of the plume measured on 25 August in the evening was emitted in a few hours, and simply integrating the concentrations 

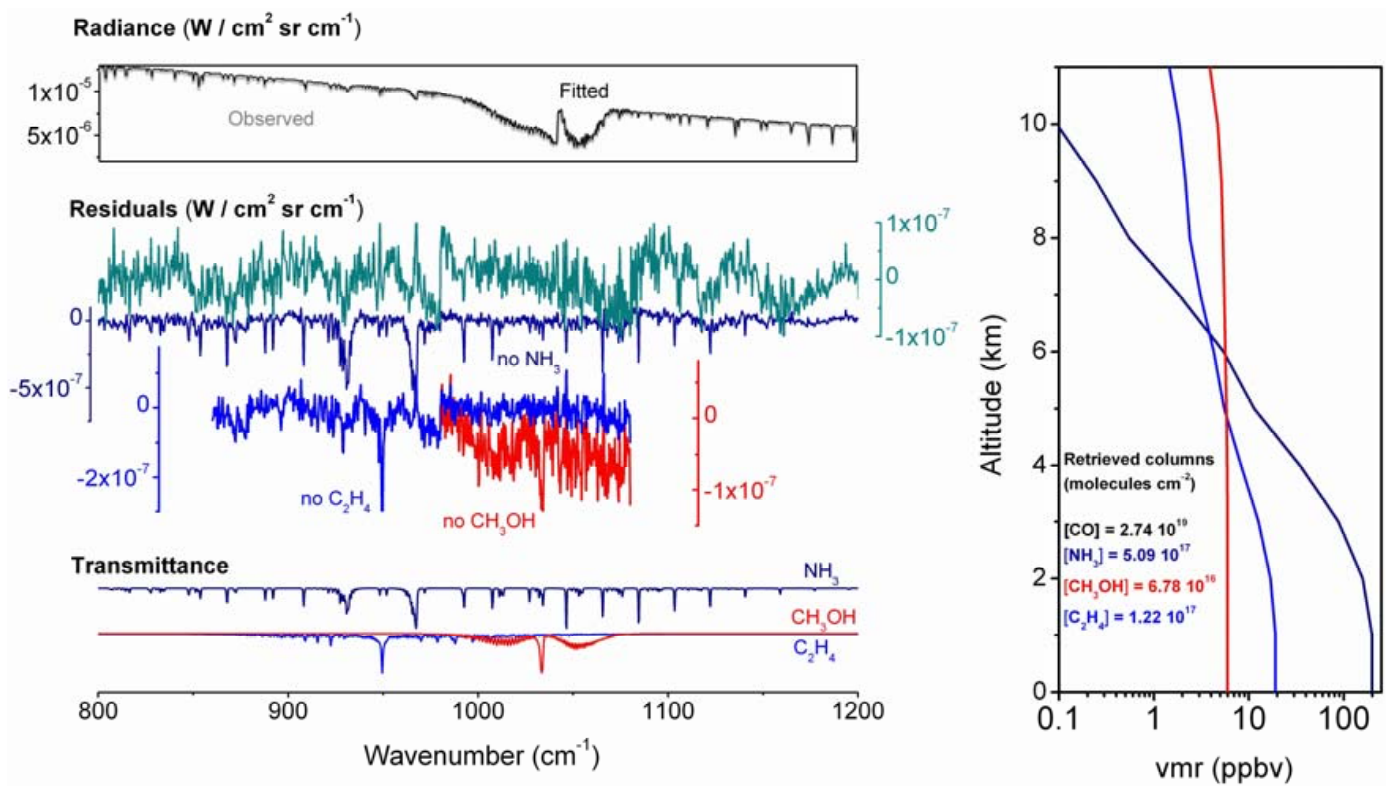

Fig. 5. Left: same as Fig. 3 for an observation of the fires from the Peloponnese on 25 August 2007 at 19:40 local time. Right: retrieved $\mathrm{NH}_{3}, \mathrm{CH}_{3} \mathrm{OH}$ and $\mathrm{C}_{2} \mathrm{H}_{4}$ profiles from that spectrum, in ppbv and on a logarithmic scale. The retrieved total columns are given inside the Figure, along with that of CO, obtained from FORLI-CO near-real-time processing (Turquety et al., 2009).

over the plume area, we estimate a total emitted mass for that particular day of $4010^{3}, 6.510^{3}$ and $7.010^{3}$ Tons for $\mathrm{NH}_{3}, \mathrm{C}_{2} \mathrm{H}_{4}$ and $\mathrm{CH}_{3} \mathrm{OH}$, respectively. Because of the already large uncertainties in the column retrieval for each individual pixels, these values are only indicative. Keeping this in mind, the $\mathrm{NH}_{3}$ plume could represent a non negligible fraction $(0.06 \%)$ of the yearly mean global emissions, and in particular of its biomass burning component (about $0.5 \%$ ) (Galloway et al., 2004). For $\mathrm{C}_{2} \mathrm{H}_{4}$ and $\mathrm{CH}_{3} \mathrm{OH}$ these would be smaller parts of the total emissions ( 0.025 and less than $0.01 \%$, respectively; Folberth et al., 2006), which would still be considerable amounts in regard to the local and brief character of the event analyzed here.

Instead of looking into the concentrations of each species individually, the chemistry patterns in the fire plumes can best be highlighted by comparing the retrieved concentrations for the short-lived compounds to that of $\mathrm{CO}$, which has a mean lifetime in the troposphere of several weeks. This procedure allows indeed removing the mixing component with ambient air, which occurs over time. This comparison is provided in Fig. 8 for the concentrations on the 25th in the evening and 26th in the morning. We find linear relations between $\mathrm{CO}$ and the other species for both days, with correlation coefficient above 0.9 for $\mathrm{NH}_{3}, 0.88$ for $\mathrm{C}_{2} \mathrm{H}_{4}$ and around 0.8 for $\mathrm{CH}_{3} \mathrm{OH}$. Despite possible large errors on the determination of the column abundance for each species, which could in turn cause large errors on the enhancement ratios if only individual scenes were considered, the observed high degree of correlation among the species provides good confidence of the reproducibility on the column measurements within a plume and as function of time. Hence, the value of the slopes $\partial[\mathrm{X}] / \partial[\mathrm{CO}]$, which give the enhancement ratio relative to $\mathrm{CO}$, is more reliable than the column themselves. Close to the fire source, however, the linear regressions are not statistically representative because of the few measurements (see Fig. 7) and the calculated enhancement ratios are provided with larger errors. Values of $0.157,0.039$ and 0.009 for $\mathrm{NH}_{3}, \mathrm{C}_{2} \mathrm{H}_{4}$ and $\mathrm{CH}_{3} \mathrm{OH}$ are respectively calculated close to the source, which are extremely high for $\mathrm{NH}_{3}$ and $\mathrm{C}_{2} \mathrm{H}_{4}$ as compared to those usually reported from aircraft measurements, even in fresh biomass burning plumes (e.g. Christian et al., 2007; Goode et al., 2000; Hobbs et al., 2003; Mauzerall et al., 1998; Yokelson et al., 2003). In fact such high values for the enhancement ratio of $\mathrm{NH}_{3}$ relative to $\mathrm{CO}$ were only reported above very specific burning sources such as cattle dung and charcoal-making kilns (Christian et al., 2007). The temporal evolution of the enhancement ratio relative to $\mathrm{CO}$ over the $24 \mathrm{~h}$ period investigated here for the Greek fires is displayed in Fig. 9, on a logarithmic scale. There is a decrease for all species, which is consistent with the shorter lifetime of these compounds compared to that of $\mathrm{CO}$. The values of the enhancement ratios for $\mathrm{NH}_{3}$ and $\mathrm{C}_{2} \mathrm{H}_{4}$ drop very rapidly, by a factor of about seven, during the first twelve hours (Fig. 9) and slower afterwards. For $\mathrm{CH}_{3} \mathrm{OH}$ the situation is similar but the rate of decrease during the first half of the period is much more reduced than for the other two species, which could be interpreted by less primary emission and possibly also secondary formation of that species in the plume (Holzinger et al., 2005). 

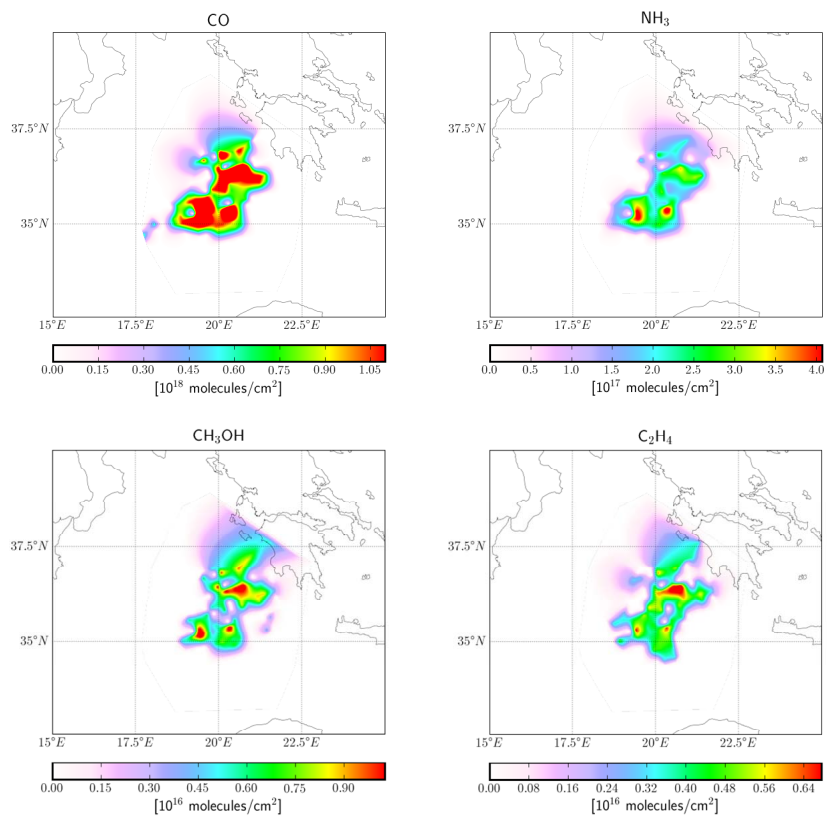

Fig. 6. Fire plume from the Peloponnese fires, measured on $25 \mathrm{Au}-$ gust 2007 at 19:40 local time, shown separately from the upper left to the bottom right, for $\mathrm{CO}, \mathrm{NH}_{3}, \mathrm{CH}_{3} \mathrm{OH}$ and $\mathrm{C}_{2} \mathrm{H}_{4}$ total columns, in molecules $\mathrm{cm}^{-2}$. For the short-lived species only the measurements showing elevated BTD values were kept for the retrievals. The CO distribution was cut for the lower total columns (values smaller than $2.8510^{18} \mathrm{~cm}^{-2}$ ) to reveal the enhanced concentrations in the plume from the background ones. Data are interpolated on a $0.125^{\circ} \times 0.125^{\circ}$ grid.

The analysis performed above for the plume of 25 to 26 August could unfortunately not be extended over a longer time period because the plume progressively disappeared and other emissions took place the following day in the same region. Similarly, such time-dependent study was difficult to perform for the South Siberia/East Mongolia fire events described above, which were not traceable in time, showing more of an intermittent character with the short-lived species being rapidly lost. As a basis of comparison, however, we find for the large plume observed on 17 May 2008, in Eastern Mongolia (see also Clerbaux et al., 2009), values of the $\partial[\mathrm{X}] / \partial[\mathrm{CO}]$ slopes of $0.013,0.011$ and 0.005 for $\mathrm{NH}_{3}$, $\mathrm{CH}_{3} \mathrm{OH}$ and $\mathrm{C}_{2} \mathrm{H}_{4}$, respectively, with, however, larger scatter around the linear regression (correlation coefficients between 0.53 and 0.73 ). These results suggest much lower ammonia and ethene emissions relative to $\mathrm{CO}$ than in the Greek fires.

\section{Conclusions and perspectives}

We have performed detailed analyses of thermal infrared radiance spectra measured from space in nadir geometry by the IASI/MetOp sounder above large forest fires. Two major events have been studied: the wildfires from August 2007 in

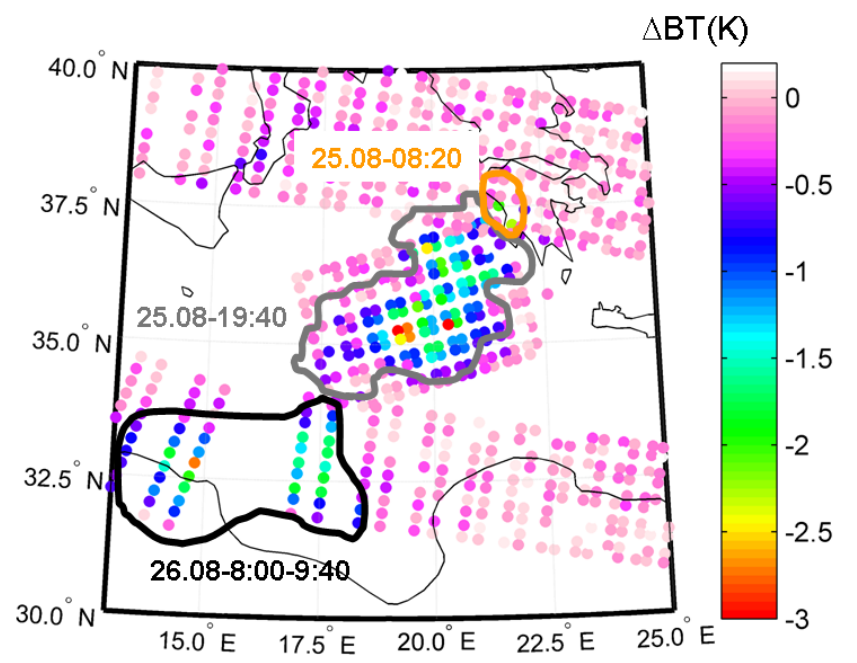

Fig. 7. IASI observation of the plume's transport from the Peloponnese fires during three successive orbits from 25 August 2007 in the morning to the next day, using $\mathrm{NH}_{3}$ as tracer. Each point represents a IASI pixel, with the colour scale giving the BTD values associated to the $\mathrm{NH}_{3}$ line at $867.75 \mathrm{~cm}^{-1}$ (negative values represent an absorption signal). Note that BTD values are given for a restricted number of measurements along the orbits; it is such as to give an estimate of the noise level outside the plume, while avoiding superposition of the values from different orbits. The orange, grey lines indicate the spatial extent of the plume for the three periods.

the Mediterranean basin, mainly originating from the Peloponnese peninsula, and those of early spring in Southern Siberia (Baikal Lake area) and Eastern Mongolia. In all these fire plumes, the presence of $\mathrm{NH}_{3}, \mathrm{C}_{2} \mathrm{H}_{4}$ and $\mathrm{CH}_{3} \mathrm{OH}$ has been firmly attested based on their spectral features in the atmospheric window. In the boreal fires, absorption bands of $\mathrm{HCOOH}$ and PAN have been observed, and the assignment of another broadband extinction feature to $\mathrm{CH}_{3} \mathrm{COOH}$ has tentatively been made. For $\mathrm{C}_{2} \mathrm{H}_{4}, \mathrm{HCOOH}$, and possibly PAN and $\mathrm{CH}_{3} \mathrm{COOH}$, these are the first reported observations from a nadir infrared sounder. Total columns have been retrieved for all species, with statistical errors generally in the range $5-30 \%(1 \sigma)$, which are to be considered as a lower bound to the total error due to the limited vertical sensitivity and unknown plume height and in addition due to the possible influence of e.g. aerosols in these extreme environments. Taking advantage of the excellent spatial resolution, coverage and sampling of IASI, the horizontal extension of the plumes have been captured and their evolutions in space and time have been tracked. We have used as a case study the fire from the Peloponnese for three successive IASI orbits to provide insight onto the capabilities of IASI to contribute in understanding the chemical processes in the plume. Enhancement ratios of $\mathrm{NH}_{3}, \mathrm{CH}_{3} \mathrm{OH}$ and $\mathrm{C}_{2} \mathrm{H}_{4}$ relative to $\mathrm{CO}$ have been inferred by linear regression analysis and the values were found to be relatively high in comparison to literature data for a young biomass burning plume. The rapid 


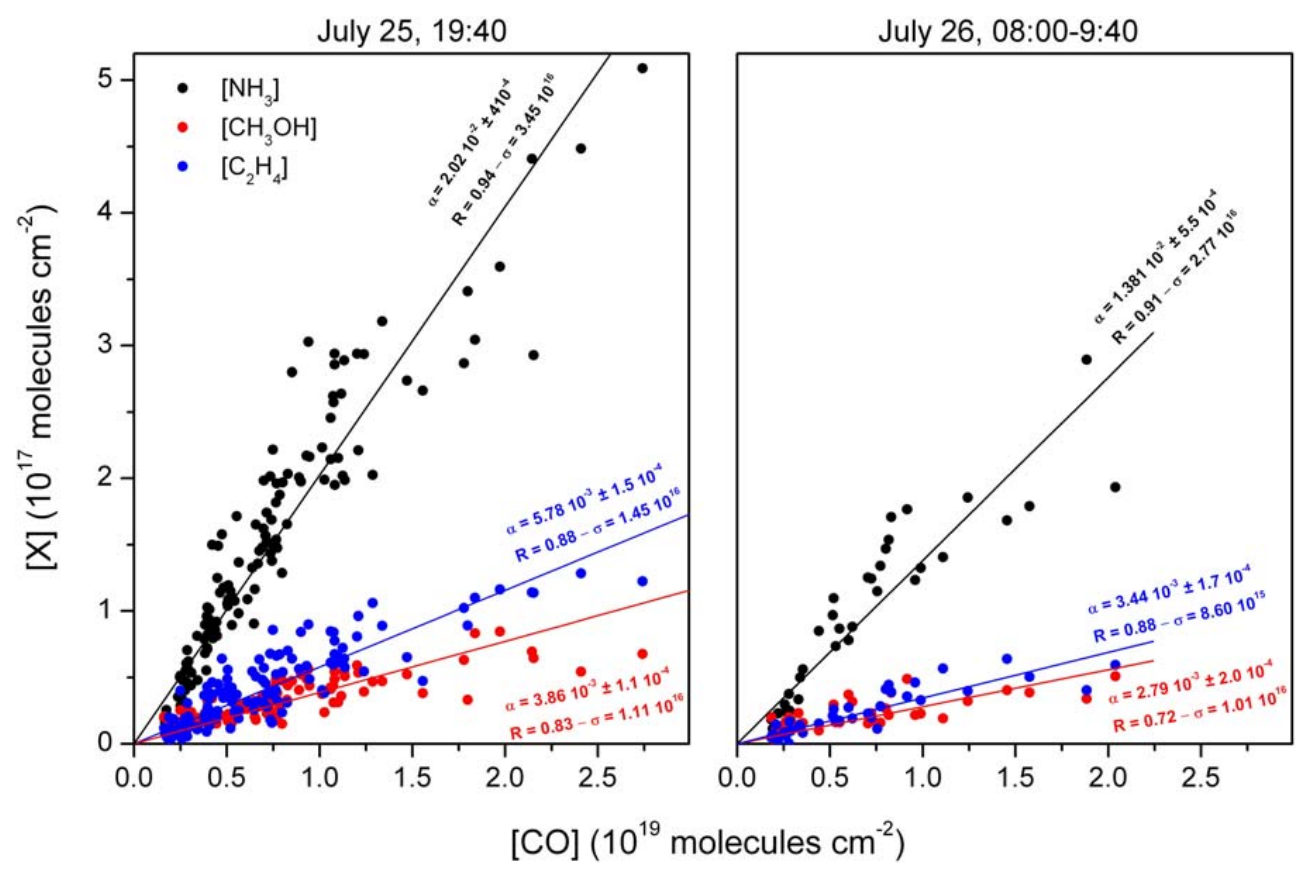

Fig. 8. Correlation between $\mathrm{CO}$ total columns and $\mathrm{NH}_{3}, \mathrm{C}_{2} \mathrm{H}_{4}$ and $\mathrm{CH}_{3} \mathrm{OH}$ total columns retrieved in the fire plume on 25 August 2007 in the evening (left) and the 26 August 2007 in the morning (right). Linear regressions are plotted for each species vs. CO. The values for the resulting slopes and their errors are given in the figure, along with the correlation coefficient $R$ and the standard deviation ( $\sigma$ ).

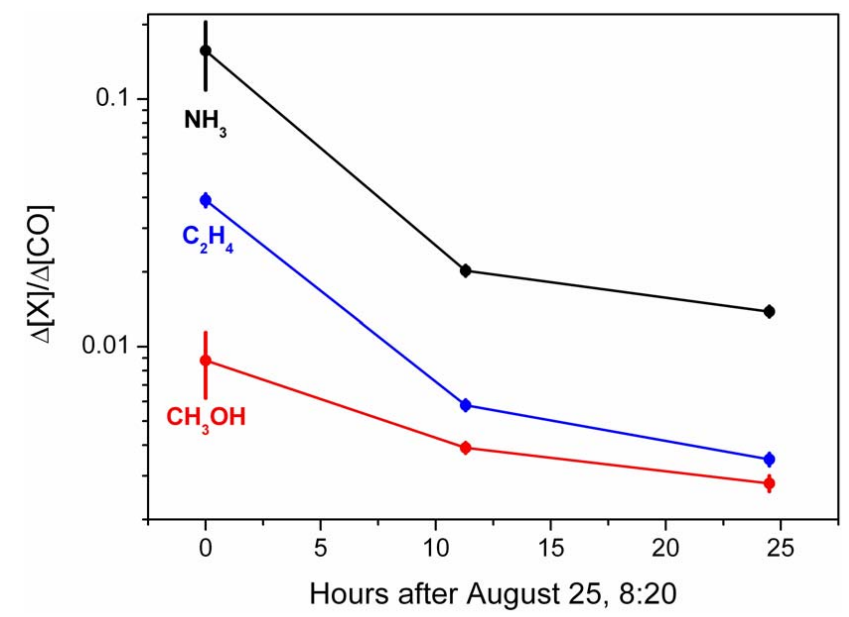

Fig. 9. Temporal evolution of the enhancement ratio of $\mathrm{NH}_{3}, \mathrm{C}_{2} \mathrm{H}_{4}$, $\mathrm{CH}_{3} \mathrm{OH}$ relative to $\mathrm{CO}$, in logarithmic scale, during the $24 \mathrm{~h}$ after the plume's first observation on 25 August 2007, closest to the source region of the Peloponnese (see Fig. 7). The error bars are standard deviation $(1 \sigma)$ from the linear regressions relative to $\mathrm{CO}$ (see Fig. 8).

decrease of the enhancement ratios after half a day is explainable by the short lifetime of these three compounds relative to that of $\mathrm{CO}$. A somewhat slower decrease of $\mathrm{CH}_{3} \mathrm{OH}$ enhancement ratios as compared to that of $\mathrm{NH}_{3}$ and $\mathrm{C}_{2} \mathrm{H}_{4}$ was found, possibly reflecting a secondary source of that species in the plume.
The analyses have suggested, using available information on the local thermal structure of the atmosphere, and assuming that the emitted plumes were largely confined to the lowest part of the atmosphere, that IASI was able to probe the chemical composition deep in the troposphere. If confirmed by more detailed forward and inverse simulations, this result would open extremely promising perspectives for identifying local to global sources of short-lived species and for monitoring air quality. This would obviously fill current observational gaps and improve our knowledge of both emission inventories and chemical reactions in the global atmospheric environment. As an example, a simple estimate of the $\mathrm{NH}_{3}, \mathrm{C}_{2} \mathrm{H}_{4}$ and $\mathrm{CH}_{3} \mathrm{OH}$ mass emissions from the Peloponnese fires on 25 August 2007 was found to make up a non negligible contribution to the global emission budgets. Since the IASI launch in October 2006 several similar strong fires have been monitored and other emission sources have been revealed. It is therefore anticipated that the continuous monitoring of the lower atmosphere by IASI for the planned 14 years will ultimately help, along with global chemistry models, to better quantify the atmospheric budgets of a series of short-lived species. A first step in reaching this objective was recently achieved from IASI global observations of atmospheric ammonia (Clarisse et al., 2009a).

Acknowledgements. IASI has been developed and built under the responsibility of the Centre National d'Etudes Spatiales (CNES, France). It is flown onboard the Metop satellites as part of the EUMETSAT Polar System. The IASI L1 data are received through the 
EUMETCast near real time data distribution service. The research in Belgium was funded by the F.R.S.-FNRS (M.I.S. nF.4511.08), the Belgian State Federal Office for Scientific, Technical and Cultural Affairs and the European Space Agency (ESA-Prodex arrangements C90-327). Financial support by the "Communauté française de Belgique - Actions de Recherche Concertées" is also acknowledged. S. Turquety and C. Clerbaux are grateful to CNES for financial support. The authors wish to thank A. Depauw for his assistance.

\section{Edited by: A. Richter}

\section{References}

Andreae, M. O. and Merlet, P.: Emission of trace gases and aerosols from biomass burning, Global Biogeochem. Cy., 15, 955-966, doi:910.1029/2000GB001382, 2001.

Beer, R., Shephard, M. W., Kulawik, S. S., Clough, S. A., Eldering, A., Bowman, K. W., Sander, S. P., Fisher, B. M., Payne, V. H., Luo, M. Z., Osterman, G. B., and Worden, J. R.: First satellite observations of lower tropospheric ammonia and methanol, Geophys. Res. Lett., 35, L09801, doi:10.1029/2008GL033642, 2008.

Boschetti, L., Roy, D., Barbosa, P., Boca, R., and Justice, C.: A MODIS assessment of the summer 2007 extent burned in Greece, Int. J. Remote Sens., 29, 2433-2436, 2008.

Burgess, A. B., Dudhia, A., Grainger, R. G., and Stevenson, D.: Progress in tropospheric ammonia retrieval from the MIPAS satellite instrument, Adv. Space Res., 37, 2218-2221, 2006.

Christian, T. J., Yokelson, R. J., Carvalho Jr., J. A., Griffith, D. W. T., Alvarado, E. C., Santos, J. C., Neto, T. G. S., Veras, C. A. G., and Hao, W. M.: The tropical forest and fire emissions experiment: Trace gases emitted by smoldering logs and dung from deforestation and pasture fires in Brazil, J. Geophys. Res., 112, D18308, doi:10.1029/2006JD008147, 2007.

Clarisse, L., Coheur, P. F., Prata, A. J., Hurtmans, D., Razavi, A., Phulpin, T., Hadji-Lazaro, J., and Clerbaux, C.: Tracking and quantifying volcanic $\mathrm{SO}_{2}$ with IASI, the September 2007 eruption at Jebel at Tair, Atmos. Chem. Phys., 8, 7723-7734, 2008, http://www.atmos-chem-phys.net/8/7723/2008/.

Clarisse, L., Clerbaux, C., Dentener, F., Hurtmans, D., and Coheur, P. F.: Global ammonia distribution derived from infrared satellite observations, Nat. Geosci., 2, 479-483, 2009a.

Clarisse, L., Coheur, P. F., Van Damme, M., et al.: Daily infrared space measurements of ammonia: the San Joaquin Valley test case, in preparation, $2009 \mathrm{~b}$.

Clerbaux, C., Hadji-Lazaro, J., Turquety, S., Mégie, G., and Coheur, P.-F.: Trace gas measurements from infrared satellite for chemistry and climate applications, Atmos. Chem. Phys., 3, 14951508, 2003, http://www.atmos-chem-phys.net/3/1495/2003/.

Clerbaux, C., Hadji-Lazaro, J., Turquety, S., George, M., Coheur, P. F., Hurtmans, D., Wespes, C., Herbin, H., Blumstein, D., Tourniers, B., and Phulpin, T.: The IASI/MetOp Mission: First observations and highlights of its potential contribution to GMES, Space Research Today, 168, 19-24, 2007.

Clerbaux, C., Boynard, A., Clarisse, L., George, M., Hadji-Lazaro, J., Herbin, H., Hurtmans, D., Pommier, M., Razavi, A., Turquety, S., Wespes, C., and Coheur, P.-F.: Monitoring of atmospheric composition using the thermal infrared IASI/MetOp sounder, At- mos. Chem. Phys. Discuss., 9, 8307-8339, 2009, http://www.atmos-chem-phys-discuss.net/9/8307/2009/.

Clough, S. A., Shephard, M. W., Mlawer, E., Delamere, J. S., Iacono, M., Cady-Pereira, K., Boukabara, S., and Brown, P. D.: Atmospheric radiative transfer modeling: a summary of the AER codes, J. Quant. Spectrosc. Ra., 91, 233-244, 2005.

Coheur, P. F., Clerbaux, C., and Colin, R.: Spectroscopic measurements of halocarbons and hydrohalocarbons by satellite-borne remote sensors, J. Geophys. Res., 108, 4130, doi:10.1029/2002JD002649, 2003.

Coheur, P. F., Barret, B., Turquety, S., Hurtmans, D., Hadji-Lazaro, J., and Clerbaux, C.: Retrieval and characterization of ozone vertical profiles from a thermal infrared nadir sounder, J. Geophys. Res., 110, D24303, doi:10.1029/2005JD005845, 2005.

Coheur, P.-F., Herbin, H., Clerbaux, C., Hurtmans, D., Wespes, C., Carleer, M., Turquety, S., Rinsland, C. P., Remedios, J., Hauglustaine, D., Boone, C. D., and Bernath, P. F.: ACE-FTS observation of a young biomass burning plume: first reported measurements of $\mathrm{C}_{2} \mathrm{H}_{4}, \mathrm{C}_{3} \mathrm{H}_{6} \mathrm{O}, \mathrm{H}_{2} \mathrm{CO}$ and PAN by infrared occultation from space, Atmos. Chem. Phys., 7, 5437-5446, 2007, http://www.atmos-chem-phys.net/7/5437/2007/.

Damoah, R., Spichtinger, N., Servranckx, R., Fromm, M., Eloranta, E. W., Razenkov, I. A., James, P., Shulski, M., Forster, C., and Stohl, A.: A case study of pyro-convection using transport model and remote sensing data, Atmos. Chem. Phys., 6, 173-185, 2006, http://www.atmos-chem-phys.net/6/173/2006/.

Dufour, G., Boone, C. D., Rinsland, C. P., and Bernath, P. F.: First space-borne measurements of methanol inside aged southern tropical to mid-latitude biomass burning plumes using the ACE-FTS instrument, Atmos. Chem. Phys., 6, 3463-3470, 2006, http://www.atmos-chem-phys.net/6/3463/2006/.

Dufour, G., Szopa, S., Hauglustaine, D. A., Boone, C. D., Rinsland, C. P., and Bernath, P. F.: The influence of biogenic emissions on upper-tropospheric methanol as revealed from space, Atmos. Chem. Phys., 7, 6119-6129, 2007, http://www.atmos-chem-phys.net/7/6119/2007/.

EFFIS: Forest Fires in Europe 2007, JRC, http://effis.jrc.ec.europa. eu/reports/fire-reports, access: July 2009, 2008.

Folberth, G. A., Hauglustaine, D. A., Lathière, J., and Brocheton, F.: Interactive chemistry in the Laboratoire de Mtorologie Dynamique general circulation model: model description and impact analysis of biogenic hydrocarbons on tropospheric chemistry, Atmos. Chem. Phys., 6, 2273-2319, 2006, http://www.atmos-chem-phys.net/6/2273/2006/.

Freitas, S. R., Longo, K. M., Chatfield, R., Latham, D., Silva Dias, M. A. F., Andreae, M. O., Prins, E., Santos, J. C., Gielow, R., and Carvalho Jr., J. A.: Including the sub-grid scale plume rise of vegetation fires in low resolution atmospheric transport models, Atmos. Chem. Phys., 7, 3385-3398, 2007, http://www.atmos-chem-phys.net/7/3385/2007/.

Fromm, M. D. and Servranckx, R.: Transport of forest fire smoke above the tropopause by supercell convection, Geophys. Res. Lett., 30, 1542, doi:1510.1029/2002GL016820, 2003.

Galloway, J. N., Dentener, F. J., Capone, D. G., Boyer, E. W., Howarth, R. W., Seitzinger, S. P., Asner, G. P., Cleveland, C. C., Green, P. A., Holland, E. A., Karl, D. M., Michaels, A. F., Porter, J. H., Townsend, A. R., and Vöosmarty, C. J.: Nitrogen Cycles: Past, Present, and Future, Biogeochemistry, 70, 153-226, 2004. 
Generoso, S., Bey, I., Attie, J. L., and Breon, F. M.: A satelliteand model-based assessment of the 2003 Russian fires: Impact on the Arctic region, J. Geophys. Res., 112, D15302, doi:10.1029/2006JD008344, 2007.

George, M., Clerbaux, C., Hurtmans, D., Turquety, S., Coheur, P.F., Pommier, M., Hadji-Lazaro, J., Edwards, D. P., Worden, H., Luo, M., Rinsland, C., and McMillan, W.: Carbon monoxide distributions from the IASI/METOP mission: evaluation with other space-borne remote sensors, Atmos. Chem. Phys. Discuss., 9, 9793-9822, 2009,

http://www.atmos-chem-phys-discuss.net/9/9793/2009/.

Glatthor, N., von Clarmann, T., Fischer, H., Funke, B., Grabowski, U., Höpfner, M., Kellmann, S., Kiefer, M., Linden, A., Milz, M., Steck, T., and Stiller, G. P.: Global peroxyacetyl nitrate (PAN) retrieval in the upper troposphere from limb emission spectra of the Michelson Interferometer for Passive Atmospheric Sounding (MIPAS), Atmos. Chem. Phys., 7, 2775-2787, 2007, http://www.atmos-chem-phys.net/7/2775/2007/.

Goode, J. G., Yokelson, R. J., Ward, D. E., Susott, R. A., Babbitt, R. E., Davies, M. A., and Hao, W. M.: Measurements of excess $\mathrm{O}_{3}, \mathrm{CO}_{2}, \mathrm{CO}, \mathrm{CH}_{4}, \mathrm{C}_{2} \mathrm{H}_{4}, \mathrm{C}_{2} \mathrm{H}_{2}, \mathrm{HCN}, \mathrm{NO}, \mathrm{NH}_{3}$, $\mathrm{HCOOH}, \mathrm{CH}_{3} \mathrm{COOH}, \mathrm{HCHO}$, and $\mathrm{CH}_{3} \mathrm{OH}$ in 1997 Alaskan biomass burning plumes by airborne fourier transform infrared spectroscopy (AFTIR), J. Geophys. Res., 105, 22147-22166, doi:22110.21029/22000JD900287, 2000.

Hauglustaine, D. A., Hourdin, F., Jourdain, L., Filiberti, M. A., Walters, S., Lamarque, J. F., and Holland, E. A.: Interactive chemistry in the Laboratoire de Meteorologie Dynamique general circulation model: Description and background tropospheric chemistry evaluation, J. Geophys. Res., 109, D04314, doi:10.1029/1023JD003957, 2004.

Herbin, H., Hurtmans, D., Clarisse, L., Turquety, S., Clerbaux, C., Rinsland, C. P., Boone, C., Bernath, P. F., and Coheur, P. F.: Distributions and seasonal variations of tropospheric ethene $\left(\mathrm{C}_{2} \mathrm{H}_{4}\right)$ from Atmospheric Chemistry Experiment (ACE-FTS) solar occultation spectra, Geophys. Res. Lett., 36, L04801, doi:10.1029/2008GL036338, 2009.

Hobbs, P. V., Sinha, P., Yokelson, R. J., Christian, T. J., Blake, D. R., Gao, S., Kirchstetter, T. W., Novakov, T., and Pilewskie, P.: Evolution of gases and particles from a savanna fire in South Africa, J. Geophys. Res., 108, 8485, doi:10.1029/2002JD00235, 2003.

Holzinger, R., Williams, J., Salisbury, G., Klüpfel, T., de Reus, M., Traub, M., Crutzen, P. J., and Lelieveld, J.: Oxygenated compounds in aged biomass burning plumes over the Eastern Mediterranean: evidence for strong secondary production of methanol and acetone, Atmos. Chem. Phys., 5, 39-46, 2005, http://www.atmos-chem-phys.net/5/39/2005/.

Hyer, E. J., Allen, D. J., and Kasischke, E. S.: Examining injection properties of boreal forest fires using surface and satellite measurements of CO transport, J. Geophys. Res., 112, D18307, doi:10.1029/2006JD008232, 2007.

Jost, C., Trentmann, J., Sprung, D., Andreae, M. O., McQuaid, J. B., and Barjat, H.: Trace gas chemistry in a young biomass burning plume over Namibia: Observations and model simulations, J. Geophys. Res., 108, 8482, doi:8410.1029/2002JD002431, 2003.

Kahn, R. A., Chen, Y., Nelson, D. L., Leung, F. Y., Li, Q. B., Diner, D. J., and Logan, J. A.: Wildfire smoke injection heights: Two perspectives from space, Geophys. Res. Lett., 35, L04809,
doi:10.1029/2007GL032165, 2008.

Labonne, M., Breon, F. M., and Chevallier, F.: Injection height of biomass burning aerosols as seen from a spaceborne lidar, Geophys. Res. Lett., 34, L11806, doi:10.1029/2007GL029311, 2007.

Langmann, B., Duncan, B., Textor, C., Trentmann, J., and van der Werf, G. R.: Vegetation fire emissions and their impact on air pollution and climate, Atmos. Environ., 43, 107-116, 2009.

Law, K. S. and Stohl, A.: Arctic air pollution: Origins and impacts, Science, 315, 1537-1540, 2007.

Martin, R. V.: Satellite remote sensing of surface air quality, Atmos. Environ., 42, 7823-7843, 2008.

Mason, S. A., Field, R. J., Yokelson, R. J., Kochivar, M. A., Tinsley, M. R., Ward, D. E., and Hao, W. M.: Complex effects arising in smoke plume simulations due to inclusion of direct emissions of oxygenated organic species from biomass combustion, J. Geophys. Res., 106, 12527-12539, 2001.

Mason, S. A., Trentmann, J., Winterrath, T., Yokelson, R. J., Christian, T. J., Carlson, L. J., Warner, T. R., Wolfe, L. C., and Andreae, M. O.: Intercomparison of two box models of the chemical evolution in biomass-burning smoke plumes, J. Atmos. Chem., 55, 273-297, 2006.

Mauzerall, D. L., Logan, J. A., Jacob, D. J., Anderson, B. E., Blake, D. R., Bradshaw, J. D., Heikes, B., Sachse, G. W., Singh, H., and Talbot, B.: Photochemistry in biomass burning plumes and implications for tropospheric ozone over the tropical South Atlantic, J. Geophys. Res., 103, 19281-19282, 1998.

Morris, G. A., Hersey, S., Thompson, A. M., Pawson, S., Nielsen, J. E., Colarco, P. R., McMillan, W. W., Stohl, A., Turquety, S., Warner, J., Johnson, B. J., Kucsera, T. L., Larko, D. E., Oltmans, S. J., and Witte, J. C.: Alaskan and Canadian forest fires exacerbate ozone pollution over Houston, Texas, on 19 and 20 July 2004, J. Geophys. Res., 111, D24S03, doi:10.1029/2006JD007090, 2006.

Pfister, G. G., Emmons, L. K., Hess, P. G., Lamarque, J. F., Thompson, A. M., and Yorks, J. E.: Analysis of the Summer 2004 ozone budget over the United States using Intercontinental Transport Experiment Ozonesonde Network Study (IONS) observations and Model of Ozone and Related Tracers (MOZART-4) simulations, J. Geophys. Res., 113, D02203, doi:10.1029/2007JD00879, 2008.

Pougatchev, N., August, T., Calbet, X., Hultberg, T., Oduleye, O., Schlüssel, P., Stiller, B., Germain, K. S., and Bingham, G.: IASI temperature and water vapor retrievals - error assessment and validation, Atmos. Chem. Phys. Discuss., 9, 7971-7989, 2009, http://www.atmos-chem-phys-discuss.net/9/7971/2009/.

Rinsland, C. P., Paton-Walsh, C., Jones, N. B., Griffith, D. W. T., Goldman, A., Wood, S. W., Chiou, L., and Meier, A.: High spectral resolution solar absorption measurements of ethylene $\left(\mathrm{C}_{2} \mathrm{H}_{4}\right)$ in a forest fire smoke plume using HITRAN parameters: Tropospheric vertical profile retrieval, J. Quant. Spectrosc. Ra., 96, 301-309, 2005.

Rinsland, C. P., Boone, C. D., Bernath, P. F., Mahieu, E., Zander, R., Dufour, G., Clerbaux, C., Turquety, S., Chiou, L., McConnell, J. C., Neary, L., and Kaminski, J. W.: First space-based observations of formic acid $(\mathrm{HCOOH})$ : Atmospheric Chemistry Experiment austral spring 2004 and 2005 Southern Hemisphere tropical-mid-latitude upper tropospheric measurements, Geophys. Res. Lett., 33, L23804, doi:10.1029/2006GL027128, 2006. 
Rinsland, C. P., Dufour, G., Boone, C. D., Bernath, P. F., Chiou, L., Coheur, P. F., Turquety, S., and Clerbaux, C.: Satellite boreal measurements over Alaska and Canada during June-July 2004: Simultaneous measurements of upper tropospheric CO, C2H6, HCN, CH3Cl, CH4, C2H2, CH3OH, HCOOH, OCS, and SF6 mixing ratios, Global Biogeochem. Cy., 21, GB3008, doi:10.1029/2006GB002795, 2007.

Rodgers, C. D.: Inverse methods for atmospheric sounding: Theory and Practice, Amosph. Oceanic Planet. Phys., World Sci., River Edge, N.J., 2000.

Rothman, L. S., Jacquemart, D., Barbe, A., Benner, D. C., Birk, M., Brown, L. R., Carleer, M. R., Chackerian, C., Chance, K., Coudert, L. H., Dana, V., Devi, V. M., Flaud, J. M., Gamache, R. R., Goldman, A., Hartmann, J. M., Jucks, K. W., Maki, A. G., Mandin, J. Y., Massie, S. T., Orphal, J., Perrin, A., Rinsland, C. P., Smith, M. A. H., Tennyson, J., Tolchenov, R. N., Toth, R. A., Vander Auwera, J., Varanasi, P., and Wagner, G.: The HITRAN 2004 molecular spectroscopic database, J. Quant. Spectrosc. Ra., 96, 139-204, 2005.

Schlussel, P., Hultberg, T. H., Phillips, P. L., August, T., and Calbet, X.: The operational IASI Level 2 processor, Adv. Space Res., 36, 982-988, 2005.

Sharpe, S. W., Johnson, T. J., Sams, R. L., Chu, P. M., Rhoderick, G. C., and Johnson, P. A.: Gas-phase databases for quantitative infrared spectroscopy, Appl. Spectrosc., 58, 1452-1461, 2004.

Stohl, A.: Characteristics of atmospheric transport into the Arctic troposphere, J. Geophys. Res., 111, D11306, doi:10.1029/2005JD006888, 2006.

Trentmann, J., Andreae, M. O., and Graf, H. F.: Chemical processes in a young biomass-burning plume, J. Geophys. Res., 108(D22), 4705, doi:10.1029/2003JD003732, 2003.

Trentmann, J., Yokelson, R. J., Hobbs, P. V., Winterrath, T., Christian, T. J., Andreae, M. O., and Mason, S. A.: An analysis of the chemical processes in the smoke plume from a savanna fire, J. Geophys. Res., 110, doi:10.1029/2004JD005628, 2005.

Turquety, S., Hadji-Lazaro, J., Clerbaux, C., Hauglustaine, D. A., Clough, S. A., Casse, V., Schlussel, P., and Megie, G.: Operational trace gas retrieval algorithm for the Infrared Atmospheric Sounding Interferometer, J. Geophys. Res., 109, D21301, doi:10.1029/2004JD004821, 2004.

Turquety, S., Hurtmans, D., Hadji-Lazaro, J., Coheur, P.-F., Clerbaux, C., Josset, D., and Tsamalis, C.: Tracking the emission and transport of pollution from wildfires using the IASI CO retrievals: analysis of the summer 2007 Greek fires, Atmos. Chem. Phys., 9, 4897-4913, 2009,

http://www.atmos-chem-phys.net/9/4897/2009/.
US Government Printing Office: US Standard Atmosphere, 1976.

Wagner, T., Beirle, S., Deutschmann, T., Eigemeier, E., Frankenberg, C., Grzegorski, M., Liu, C., Marbach, T., Platt, U., and de Vries, M. P.: Monitoring of atmospheric trace gases, clouds, aerosols and surface properties from UV/vis/NIR satellite instruments, J. Opt. A-Pure Appl. Op., 10, 104019, doi:10.1088/14644258/1010/1010/104019, 2008.

Wan, Z. M.: New refinements and validation of the MODIS LandSurface Temperature/Emissivity products, Remote Sens. Environ., 112, 59-74, 2008.

Warneke, C., Bahreini, R., Brioude, J., Brock, C. A., de Gouw, J. A., Fahey, D. W., Froyd, K. D., Holloway, J. S., Middlebrook, A., Miller, L., Montzka, S., Murphy, D. M., Peischl, J., Ryerson, T. B., Schwarz, J. P., Spackman, J. R., and Veres, P.: Biomass burning in Siberia and Kazakhstan as an important source for haze over the Alaskan Arctic in April 2008, Geophys. Res. Lett., 36, L02813, doi:10.1029/2008GL036194, 2009.

Wespes, C., Hurtmans, D., Clerbaux, C., Santee, M. L., Martin, R. V., and Coheur, P. F.: Global distributions of nitric acid from IASI/MetOP measurements, Atmos. Chem. Phys. Discuss., 9, 8035-8069, 2009, http://www.atmos-chem-phys-discuss.net/9/8035/2009/.

Worden, H., Beer, R., and Rinsland, C. P.: Airborne infrared spectroscopy of 1994 western wildfires, J. Geophys. Res., 102, 12871299, 1997.

Yokelson, R. J., Goode, J. G., Ward, D. E., Susott, R. A., Babbitt, R. E., Wade, D. D., Bertschi, I., Griffith, D. W. T., and Hao, W. M.: Emissions of formaldehyde, acetic acid, methanol, and other trace gases from biomass fires in North Carolina measured by airborne Fourier transform infrared spectroscopy, J. Geophys. Res., 104, 30109-30125, 1999.

Yokelson, R. J., Bertschi, I. T., Christian, T. J., Hobbs, P. V., Ward, D. E., and Hao, W. M.: Trace gas measurements in nascent, aged, and cloud-processed smoke from African savanna fires by airborne Fourier transform infrared spectroscopy (AFTIR), J. Geophys. Res., 108, 8478, doi:10.1029/2002JD002322, 2003. 